\title{
The Governance of Contracts: Empirical Evidence on Technology Licensing Agreements ${ }^{\circ}$
}

\author{
Eric Brousseau*, and Régis Coeurderoy**, and Camille Chaserant*** \\ *EconomiX, Université de Paris X, and Institut Universitaire de France \\ ** CRECIS, Université Catholique de Louvain, School of Management \\ *** EconomiX, Université du Havre
}

Corresponding author:

$\underline{\text { Eric Brousseau }}$

EconomiX, Université de Paris X, Bâtiment K, 200 avenue de la république, F-92001 Nanterre Cedex, France

Tel: +33 (0)1.40.97.59.22 — Fax: + 33 (0)1.40.97.59.07 — eric@brousseau.info

This Version June 2006

\begin{abstract}
:
This paper provides new evidence on the contractual governance of technology licensing agreements. Based upon an international sample of licensing contracts, we explore how the contractual design deals with specific contractual hazards. In particular, we comparatively assess the influences of transaction attributes, institutional frameworks and strategic considerations on licensing design. Empirical results highlight that contractual clauses of governance are crafted independently of each other. This leads to a discussion about complementarities among contractual components, which is frequently assumed in theory. Furthermore, our results are certainly amongst the first to provide econometric evidence on the pervasive influence of private institutions in technology trade.
\end{abstract}

\footnotetext{
- This paper is based on a survey carried out among the members of the Licensing Executive Society, International (LESI). This survey received the support of the LESI and from the LES-USA-Canada. LES France also actively helped in the realization of this research. LESI members and executives are warmly thanked for their support. We are grateful for the useful comments made by the participants and discussants to various seminars that helped to improve an earlier version of this paper. We are also indebted to the referees of this journal for helpful suggestions. We also thanks Christian Bessy (CNRS, CEE) who helped us on the survey and the data and Jean-François Sattin (ATOM \& UTC) and Stéphane Saussier (ATOM \& U. of Paris XI) for helpful comments Usual caveats apply
} 


\section{1-Introduction}

As pointed out by many authors (e.g. Caves et al. (1983), Bessy and Brousseau (1998), Anand and Khanna (2000), Arora and Fosfuri (2002, 2003), among others), the transfer of knowledge among firms is complex to perform and subject to many hazards. The licensor (henceforth referred to as he) has little or no ex post control over how the intangible assets transferred to the licensee (she, hereafter) are used, while the latter can use what she has learnt in competition against her former partner. These hazards raise transaction costs as well as hinder the development of technology transfers, itself a main concern for both innovators and policy makers alike. The fact that patent owners miss opportunities to reap the full revenues of their inventions, will ultimately translate to a negative impact on collective welfare. That is the under-diffusion of inventions and the under-rewarding of innovators will diminish the innovators incentives and capabilities to innovate. In this context, it is essential to understand how firms can build efficient contracts to deal with transactional hazards. It is also necessary to analyze how more efficient institutional frameworks could be designed to decrease the cost of trading intangible goods in order to allow for the emergence of "markets for technologies" enabling to maximize diffusion (Arora et al. 2001).

A better understanding of contractual practices in the field of technology transfer will induce progression, both in the specifics of knowledge transfers (which is covered by the literature on technology alliances, e.g. Oxley and Silverman, 2006; on technology licensing e.g. Bessy and Brousseau, 1998; Arora et al, 2001; and on optimal Intellectual Property Rights regime, e.g. Scotchmer and Gallini, 2006; Jaffe and Lerner, 2004), and in the wider field of contractual design. Indeed, the analysis of the design of contractual mechanisms and their combination in a contract is still in development. The existing literature can be divided into two broad areas. The first is dedicated to an in-depth analysis of contractual components - especially incentive schemes and retaliation mechanisms - that are analyzed (either theoretically or empirically) independently of the other features of the contracts. The second branch of the literature - especially in the Transaction Cost (e.g. Williamson, 1985) or Incomplete Contract perspectives (e.g. Grossman and Hart, 1986; Hart and Moore, 1988) — contrasts contractual logics (e.g. market vs. hybrid vs. hierarchy, or transactional vs. relational contracting). Aside from the fact that these two streams of literature ultimately relate to contrasting analytical traditions, because of the under-development of the analysis of potential interaction between contractual provisions, reconciliation between the two streams is difficult. By considering the relationships between the provisions that organize governance, this paper provides a contribution to such an analysis.

This paper is an applied contribution both to the analysis of contractual design and to the analysis of technology transfer. The aforementioned literature on Technology Licensing Agreements (TLAs) shows that such agreements are usually established in the long run in uncertain contexts. This is due to the fact that technological changes may occur and the fact that complex strategic games may be played around the technology (e.g. Gallini and Winter, 1985, Shepard 1987, Jorde and Teece, 1990, Kamien, 1992) and around the alliances (e.g. Oxley and Silverman, 2006). This situation leads contracting parties to implement sophisticated "governance" mechanisms to adjust their mutual commitments during the lifetime of the contract. We focus on the supervision, renegotiation, and dispute resolution mechanisms both on an individual and combined basis. Evidence provided is based on a database of 213 licensing contracts. Data has been collected through a survey answered by 160 American, Japanese and European firms, principally in chemical, equipment and service 
based industries (See Brousseau, Chaserant and Bessy, 2005 and Brousseau, Chaserant Bessy, Coeurderoy, 2005).

We first develop our analytical framework (2), and then present the data and the research design (3), before discussing the results (4). We conclude that governance mechanisms implemented by contracts strongly depend upon transaction characteristics, the institutional framework - especially for the case of private institutions - , and the level of potential competition among the parties. We refer to the issue of interdependence among contractual provisions and consider that the nature of the potential complementarities deserves further research (5).

\section{2-Theoretical Framework and Expected Causal Relationships}

Contributions like those by Bessy and Brousseau (1998), Anand and Khanna (2000), Arora and Fosfuri $(2002,2003)$ pointed out that the shape of technology licensing agreements is strongly influenced by both the resources that are actually transferred between the parties and the institutional setting. This is consistent with the two main lines of analyses developed by New-Institutional Economics (NIE) to explain the design of governance mechanisms: the transactions' features pointed out by Williamson $(1975,1985,1996)$; and the Institutional Environment, especially as analyzed by Barzel (1989) and North (1990). However, these contributions did not take into account the role of strategic behaviors, which are of particular importance in the case of TLAs. Indeed, as pointed out by Industrial Organization (Kamien, 1992), many TLAs are explained by other necessities than the governance of the transaction per se. TLAs can be set-up in the framework of alliances aimed at controlling the development of technology, standards, or foreclosing a market (e.g. Gallini and Winter, 1985, Shepard 1987, Jorde and Teece, 1990). Such biases should impact on the structure of contracts. However, to our knowledge, there is little empirical evidence of the impact of these strategies on contractual features.

In this paper we point out how contractual provisions are influenced by these three types of determinants: the characteristics of transactions, the institutional environment and the strategic behavior of agents (2.1). We then develop the analysis of the design of governance mechanisms by highlighting the main trade-off which agents have to consider (2.2). This leads us to forming testable propositions (2.3)

\section{1- The Economics of Contractual Design}

The transfer of knowledge generates hazards. Once transferred, it is hardly possible for the patentee/licensor to withdraw the knowledge from the licensee. The licensee can either use it without paying any compensation to the inventor, thereby depriving him of expected revenues, or worse can use it to actually harm the licensor. For instance, the inventor's insights can be the basis for innovations that will surpass the licensor's own technical solutions. He will therefore try to control these transactional hazards through the implementation of contractual commitments and governance mechanisms aimed at deterring opportunistic behavior. Three categories of solutions to preventing such hazards can be implemented. First, positive incentives can be implemented in contracts in order to encourage the licensee to take the appropriate action. However, since the licensee expects nothing more from the inventor after the (sunk) transfer of knowledge is made, her ex post behavior is hardly controllable by incentives. Second, dissuasion mechanisms can be implemented so as 
to deter the licensee from behaving opportunistically. Third, as pointed out by Crocker and Masten (1991), allowing parties to readjust contractual obligations in an effort to realign their incentives for cooperation throughout the lifetime of the contract is also a way to ensure the completion of the contract.

These solutions are generally implemented thanks to a governance mechanism that allows the parties to govern their relationship ex post. The three main functions of which governance is comprised are as follows: the supervision of ex post party behavior, the process of ex post renegotiation and the process of solving potential party conflict. We therefore analyze the choices that are made by the parties with regard to the design of supervision, renegotiation and conflict settlement provisions. In addition, we check whether these choices are independent.

We assume that agents balance the costs of the mechanism they implement with the benefits they draw from adequate governance; i.e. a reduced risk of ex post-misalignment of their behaviors and a reduced risk of shirking by the parties (and the associated losses due both to the breach and to the costs of the resulting conflicts). Three categories of factors influence this trade-off: (i) the transactional attributes of technology transfer; (ii) the strategic behavior of contracting parties; and (iii) the characteristics of the institutional environment.

(i) The features of the transaction (in the sense of Williamson, 1975, 1985) impact on the likelihood of opportunistic behavior, and on the level of potential losses for the contracting parties.

One of the main characteristics of transactions pointed out by TCE is asset specificity. This refers to the sunk investments borne by the parties in certain transactions, which lock them into a bilateral relationship. In the case of TLAs, sunk costs are linked to the difficulty of transferring and absorbing knowledge. As pointed out in Bessy and Brousseau (1998), the wording of a patent does often not encompass the knowledge necessary to implement the protected technological solution. In addition to the right to use the license, complementary resources (such as secrets, red-books, prototypes, training and consultancy services, etc.) are transmitted by the licensor to the licensee These transfers require efforts by both parties that are sunk in the case of a contractual breach. They then correspond to investments that are specific to this relationship.

(ii) The parties are also potentially involved in a strategic game regarding the use of technology. Transactions of knowledge are specific in the sense that knowledge can be used by the beneficiary of the sunk transfer in a way that will directly harm the competitive position of the inventor or the inventor's ability to gain returns on his investments. More precisely, the licensee may follow two opportunistic strategies ${ }^{1}$ :

(a) She may "invent around" the transferred knowledge, or learn things that are not licensed, and therefore compete against the licensor.

(b) In the case of competition among alternative technological solutions, a technological competitor may ask for a license and under-use it so as to hinder the diffusion of the

\footnotetext{
${ }^{1}$ We exclude here the situation in which the licensee does not pay due royalties since it is not a behavior that can be qualified as "strategic". While it harms the licensor's wealth, it does not increase the licensee's ability to compete against the licensor in the innovation race.
} 
licensed technology. Indeed, if there are strong positive returns of adoption (David, 1985), limiting the diffusion of a technology can increase the probability of competing technologies succeeding.

The probability and the nature of potential losses inflicted on the inventor depend upon the specific characteristics of the technological competition and of the relative competitive position of the licensee.

(iii) The relationship between licensors and licensees is also affected by the nature of the institutional environment (in the sense of Barzel, 1989 and North, 1990). Indeed, these institutions provide tools - rights, rules, dispute resolutions mechanisms, etc. - that can be relied on by agents so as to facilitate any dealings, while the discrepancies between generic coordination resources and specific coordination needs result in the necessity to design bilateral governance mechanisms (Brousseau and Fares, 2000, Brousseau and Raynaud, 2006).

The institutional framework is made up of public institutions (such as the legal system) and private institutions (such as among others, industry unions and trade associations). Public institutions establish property rights that can be traded among agents so as to transfer the rights of use and get benefits from their exploitation (Barzel, 1989, North, 1990). Nevertheless, public institutions always design an incomplete property rights system. It would be prohibitively costly to implement a complete system, recognizing in advance an owner of exclusive rights for any potential uses of a good, and developing the means of supervision and punishment to prevent any infringement. Agents perform therefore a wide range of operations necessary to actually implement transferable and exclusive rights of use (North, 1990). This is especially the case with IPRs (Brousseau, 2004, Brousseau and Bessy, 2005). Public institutions incompletely define IPRs, and all else being equal, economic agents must dedicate a substantial amount of resources to claim and transfer exclusive rights regarding the use of knowledge. To reduce these costs, they may rely on private institutions (Brousseau and Raynaud, 2006); i.e. on collective governance resources aimed at facilitating the establishment and the transfer of property rights. The governance of licensing contracts is then influenced by the characteristics of both public institutions (which are generally defined at the national level) and private institutions (more often created at the industry level).

\section{2- The Three Components of Governance}

In what follows we highlight the trade-offs at the basis of the design of each components of a governance mechanism. In the case of TLAs, we focus on the contractual hazards emanating from the licensee. The licensor could be opportunistic, but the asymmetry between the levels of relational risk for each party is wide. The licensee acquires access to the licensor's strategic assets - namely his knowledge, but also his reputation - while the reverse is generally not the case. The licensee can therefore harm the licensor to a far greater degree than can the licensor harm the licensee. At the same time the licensor can be opportunistic in two ways. Firstly, since the licensee does not know everything about the technology prior to the transfer, there is a classic adverse selection issue. The technology could be overpriced due to the inability of the licensee to really assess its value and quality. Secondly, the licensor might actually renege on providing the licensee with the know-how needed to implement the transferred technology (Arora, 1995). The responses to both hazards are traditionally dealt ex 
ante thanks to an adequate design of the payment formulae. The implementation of royalty payments in particular, is aimed at controlling these hazards ${ }^{2}$. While they may protect the licensee, they increase her ex post ability to harm the licensor (by the stoppage or underpayment of royalties), an ability which is controlled by governance mechanisms (which are also aimed at controlling other potential mis-behaviors). This is the reason as to why governance clauses tend to address the licensee's potential for opportunism rather than the licensor's. This vision is shared by most researchers working on transfers of knowledge and technology (see, for instance, Oxley, 2006).

\section{1- Supervision and the Ability to Retaliate against Opportunism}

A contractual agreement grants audit rights to one of the parties (or to a third party) in order to check that contractual commitments are being enforced. While supervision does imply a degree of effort, it should result in a reduced level of shirking. All else being equal (in particular the cost of retaliation borne by the guilty infringers), rising supervision increases the expected costs of opportunism.

It is now widely recognized that supervision is initially needed when the licensor can ex -ante fear opportunistic behavior by the licensee. That is, when sunk investments in the relationship, and risks of hold-up occur (Williamson, 1985; Gatignon and Anderson, 1988).

It makes sense however to implement supervision provisions only if the supervisor can provide evidence of infringement to a court. Indeed, if mutual obligations are hazy, or if no external efficient mechanism of enforcement is available, it is useless to contractually implement right of audit in the contracts. Indeed in the latter case, parties will either refuse the contract, or, rely on their own ability to informally supervise and retaliate.

\section{2- Renegotiation and the Ability to Reduce Cost of Adjustment}

A renegotiation provision states the extent to which contractual obligations will ex post be redesignable to adjust contractors' behavior either to new environmental conditions, or to the evolution of mutual preferences, or indeed to the accumulation of knowledge. When a renegotiation provision is implemented, parties agree to renegotiate only part of the mutual commitment; meaning that its other components stay in place ${ }^{3}$. This is a means to gaining

\footnotetext{
${ }^{2}$ In fact, the first hazard (supply of the complementary know-how) requires at least two steps in the payment process: the first payment at the time of the signature of the agreement; the second payment, once the necessary know-how has been provided by the licensor to the licensee (See Arora, 1995). The second hazards (over-pricing of the technology) is controlled by the implementation of royalties per se, since this is the only way for the licensee to pay the technology as a function of its actual commercial usefulness. In both cases, the payment formula reinforces the ex-post dependency of the licensor from the licensee's behavior.

${ }^{3}$ A contractual arrangement is legally bidding: both parties have to enforce contractual obligations as they were initially written. When there is no renegotiation provision and if the judge does not force the parties to apply the wording of the contract (specific performance), AND if both parties agree to renegotiate, then the contract can be renegotiated. However in that case everything is as if all the dimensions of the contract were renegotiable. Indeed, a contract is a system of mutual commitments that are interdependent. If a party wants to lift some of its obligations, then he has to compensate the other in exchange... and the whole set of ex-ante mutually agreed obligations collapse and have to be renegotiated. This is not the case when a renegotiation provision is implemented. In this case, parties can renegotiate part of their obligations, without considering those that are not open to renegotiations. This channels renegotiations and bring (re)negotiation costs down, while increasing the reliability of mutual obligations.
} 
flexibility while avoiding excessively high renegotiation costs. As pointed out by Croker and Masten (1991), a renegotiation clause provides the agents with incentives not to shirk (since they can adapt to new situations) and reduce the level of misalignments, since it makes adaptation less costly. The "cost" of such a provision however, is that parties benefit from weaker contractual protection. In addition, all else being equal, such a provision raises the probability of renegotiation.

Therefore, parties only implement such a clause when ex post mutual adjustment is really needed. This happens when uncertainty is high. Indeed, in this case it is too costly to ex ante write down a complete contingent contract (Williamson, 1985, Crocker and Masten, 1991). It is also positively correlated with the expected duration of the relationship, since it is a factor of higher uncertainty - the complexity of the world makes it harder to foresee the future in the long term than in the short term - and since the opportunity cost of non-adaptation linearly increases with duration.

However, a renegotiation provision tends to reduce the credibility of ex ante commitments. This could then favor the development of opportunistic behavior, ruining the positive incentives provided by flexibility (in particular, the incentives to specifically invest in the relationship). A renegotiation provision will therefore be implemented in a contractual agreement if two enabling conditions arise:

- First, parties should not have interests that are too divergent in nature. Indeed, if they play a zero-sum game (e.g. when they are direct competitors), they will be unable to reach any agreement ex post.

- Second, as pointed out by MacNeil's seminal paper (1974) on relational contracting, the institutional framework can facilitate renegotiations. Indeed, by channeling agents' behavior and by influencing their beliefs, institutions - especially informal ones impact on their willingness to behave fairly and therefore on the likelihood of reaching agreements.

\section{3- Dispute Resolution Mechanisms and the Ability to Reduce the Cost of Conflicts}

Contracts are enforceable by courts as a final recourse. However, according to Williamson (1985), courts can be inefficient in resolving disputes, especially when contractual breach is costly and when transactions tend to be unique (because the judge has to learn everything about the case). An Alternative Dispute Resolution (ADR) provides the benefit of specialized arbitrators, which in itself reduces verifiability constraints. In addition, arbitration may be subject to constraints such as delays or confidentiality. Altogether, it will enhance the efficiency of the dispute resolution process. There is however a tradeoff between the efficiency gain obtained by the contractors, and the fact that they have to internalize the costs of dispute resolution when they implement a related provision in the contract (see Bernstein, 2001 ; Hadfield, 2005)

On the one hand, parties are likely to implement an ADR mechanism when unverifiability is high. This is the case when exchanges between parties are difficult to observe and assess by a third party. Indeed, this is especially the case if specific knowledge is needed. On the other hand, conflict among parties can hinder the recourse to such a procedure because there is no mechanism of appeal in an ADR. Parties with strong antagonistic interests would hardly agree to give-up their ability to play complex games in the event of conflict resolution, or to abandon the possibility of appeal in the case of sentencing. 


\section{3- Testable Propositions}

The previous developments allow us to draw testable propositions about the design of governance mechanisms. However in the specific case of TLAs, the general analytical categories usually used in transaction cost should be adapted to the peculiarities of the transferred resource, i.e. knowledge.

Transfers of knowledge are of high risk for the licensor, since they are irreversible. It is impossible to force the licensee to "unlearn". Judicial means allow the licensor to prevent the licensee from directly competing with him, but it is obvious that the latter remains able to use the transferred knowledge to invent and compete "around"; i.e. to use the knowledge to either bypass the licensor's patent or to invent competitors to that patent. Such transactional hazards are expanded by another feature of knowledge. Since knowledge is not fully codifiable, the wording of a patent does not encompass all the knowledge that is necessary to turn a "mother idea" into a "technical realization", and a fortiori into a marketed product or service. A patentee therefore needs to transfer unpatented knowledge to the licensee. In concrete terms the licensor should often provide prototypes, red-books, data-files, counsel, and train or delegate personnel ${ }^{4}$. These make the transaction more complex to manage, and also increase contractual hazards. Tacit knowledge in particular makes the delineation of property rights problematic and increases appropriability hazards (Teece, 1986; Oxley, 1999).

\section{1- Supervision Provision}

In the case of transfers of knowledge, the level of contractual hazards is strongly dependent on two factors: the scope of the transfer and the degree of potential competition between the parties. As pointed out above, when a lot of additional cognitive resources have to be transferred by the licensor to the licensee, both the costs and the value of what has been transferred to the licensee (which is therefore appropriable by him) are higher.

Moreover when the two parties are direct competitors, the knowledge that is useful for one of the parties can directly be exploited by the other. This is not the case for firms operating within different markets.

H1a The higher the "intensity" and "sunkedness" of the transfer, the more likely is the implementation of a supervision clause

H1b The higher the degree of potential competitive conflict between the parties, the more likely the implementation of a supervision clause

However, a supervision provision is a safeguard if and only if the institutional environment can guarantee enforcement. If the rights granted to an IPR holder are ambiguous or if the

\footnotetext{
${ }^{4}$ The nature, number and diversity of cognitive resources to be transferred vary from one transaction to another. In some technical domains both parties have the same knowledge (but do not share the same rights of use), while in other domains the cognitive abilities of parties strongly differ. We will therefore refer to the scope of the transfers of resources between the parties that refer both to the costs and the risk incurred by the parties when transferring knowledge. In our opinion, the intensity of transfers should be considered as equivalent to the notion of investment in specific assets of common use in TCE (Teece, 1977). This is because it relates to the cost of transfers (which are sunk) and to the level of risk.
} 
court is inexperienced in dealing with conflicts over technology transfers, the parties will ex ante prefer to rely on their own ability to informally retaliate. Thus, H1a and $\mathrm{H} 1 \mathrm{~b}$ are subjected to the condition:

H1c The higher the "quality" of formal institutional environment, the more likely is the implementation of a supervision clause

\section{2- Renegotiation Provision}

As pointed out in section 22, the implementation of a renegotiation provision should be positively related to the need for flexibility. Generally speaking it is related to both the level of uncertainty in the strategic environment - which ex ante, makes it harder to implement an efficient set of mutual commitments - and to the expected length of the relationship which given a level of environmental uncertainty, means that the longer the horizon, the greater is the necessity of the adaptation of the contract.

In the specific case of TLA, uncertainties about technological evolutions are of a special importance. When technological uncertainty increases, the traded technology is more likely to become obsolete before the end of the contract, either because the parties will invent new solutions, or because competitors will develop new technologies. The value of the transfer and even its justification can therefore be "questioned" ex post. Thus

$\mathrm{H} 2 \mathrm{a}$ The higher the technological uncertainty of the transfer, the more likely the implementation of a renegotiation clause

$\mathrm{H} 2 \mathrm{~b}$ The longer the expected horizon of the relationship, the more likely the implementation of a renegotiation clause

However, an institutional condition is also needed. To avoid uncredible commitments, renegotiations provisions are to be implemented if the institutional environment guarantees that future renegotiations will be framed, especially by informal institutions (MacNeil, 1974). Therefore:

$\mathrm{H} 2 \mathrm{c}$ The higher the "quality" of institutional environment - especially of private institutions -, the more likely the implementation of a renegotiation clause

\section{3- Alternative Dispute Resolution Mechanisms}

Since transfers of technology can request the transfer of many resources, in particular tacit knowledge, which are hardly protected by the IPRs system and more generally by the formal public institutions, public and generic conflict resolutions mechanisms tend to be adapted improperly. Judges are unable to verify these complex relationships and can hardly rely on legal categories to make decisions. The patentee will prefer to keep secret the details of the conflict he might have with his licensee. This is because the weak protection provided by the IPRs system would allow any third party assessing the evidence provided during the hearings, access to part of the licensor's knowledge and to use it. Consequently, all else being equal, the incentive to rely on an ADR increases with the intensity of the resources transferred to the licensee. This is because such an increase corresponds both to lower verifiability and to lower protection of property rights by the public IPRs system. Therefore

H3a The higher the "intensity" of the transfer, the more likely the implementation of an ADR mechanism 
As pointed out above, the recourse to an ADR should be hindered by conflictuality among parties. Thus

$\mathrm{H} 3 \mathrm{~b}$ The higher the strategic stakes between partners, the less likely the implementation of an ADR mechanism

Any decision to settle conflicts outside the public judicial system is made only when ex post, one party considers the other likely to enforce the sentence made by the arbitration tribunal. Moreover, the chances of agreement on a common procedure should increase with the fact parties have shared beliefs. The implementation of an ADR should be facilitated by the parties' inclusion in common relational networks and informal institutional frameworks.

H3c The higher the inclusion in relational networks and involvement in "private" institutions, the more likely the implementation of an ADR mechanism

\section{4- Complementarities among contractual clauses}

Given that the three governance provisions we analyze address different transactional difficulties, we do not expect strong dependencies between the three.

H4 The settling of supervision, renegotiation and dispute resolutions provisions is likely to be independent from each other

\section{3- Data and Research Design}

\section{1-The Database}

Our analysis is based on a database developed in collaboration with the Licensing Executive Society International (LESI), a business-oriented international organization grouping professionals involved in licensing and other aspects of intellectual property rights transfers.

We carried out a survey among LESI members to investigate their technology licensing practices. A questionnaire was established with members of LES USA-Canada and LES France. It was sent to 2185 firms, mainly in Europe (35.5\%), Japan (13.0\%) and North America - USA and Canada - (48.5\%). Information about licensing practices, however, is still widely considered as highly confidential by companies and they remain reluctant to answer. For that reason, despite the support of LESI, only 160 questionnaires were completed and sent back. They describe 297 licensing technology agreements considered by the respondents as "reflecting their most current practices".

In our view, the relatively small response rate is compensated by the details gathered on each agreement, which is described by 70 variables. Other empirical research based upon surveys is also confronted with firms' reluctance to disclose information on these issues. Information is thus often scarce and samples rather small in size. For instance, Davies (1977) investigates 26 cases; Davies (1992) 204 cases; Macho-Stadler et al. (1996) 240 cases; Aulakh, Cavusgil and Sarkar (1997) 110 cases; Chi and Roehl (1997) 93 cases; and Bessy and Brousseau (1998) 46 cases. By comparison with previous studies, we managed to get a relatively large and 
diverse, cross-country and cross-industry sample of licensing agreements. After the discarding of incomplete responses, 213 questionnaires remained ${ }^{5}$.

The questionnaire was divided into two parts. The first part was devoted to a general presentation of the respondent firm, its organization, its licensing goals and its industrial and institutional environments. In the second part, we asked the respondents to provide information about the characteristics of licensing agreements they consider as "the most representative of their activity". Afterwards information on licensing conditions, payment formulas, safeguards and governance structure was collected.

Responses came from three economic zones: North America, Japan and Europe. We collected a few questionnaires in the rest of the world, but not enough for statistical analysis. North American firms account for $60 \%$ of our sample, European firms $30 \%$ and Japanese firms $10 \%$. Because of the size of the US market, and also because the American firms in our sample are on average smaller than the European and Japanese respondents, there is a greater share of US initiated TLAs that are purely domestic. The contracts initiated by European and Japanese firms tend to be more oriented toward international exchanges. This is especially the case for Japanese contracts, since Japanese firms in our sample are very large and highly internationalized ${ }^{6}$.

We divided these firms into four principal sectors according to their main activities. That is, firms whose activities are related to the transformation of raw materials $(11.7 \%)$, related to chemicals $(41.3 \%)$, related to equipment manufacturing and sales $(23.0 \%)$ and related to services $(17.8 \%)$. The remaining firms, whose activities are more varied, belong to what we called the "other" sector $(6.1 \%$; cf. Table 1$)$.

$<$ insert table $1>$

Our database is mainly composed of licensing-out agreements (the respondent is the licensor). As License-in and license-out contracts are not significantly different, we do not distinguish between the two in our analysis. Almost $60 \%$ of our database agreements are sole licenses. The others are included either in a cooperative R\&D project or in a wider alliance or a partnership. All these characteristics are summarized in the following Table 2.

$$
<\text { insert table 2> }
$$

\footnotetext{
${ }^{5}$ It would be quite impossible to assess the representativeness of such a sample since the real number of licenses throughout the world remains unknown. However, since our contracts cover a wide range of situations (domestic and international exchanges, intra and inter-industry transfers, trade among independent firms and firms that have equity links, diversity of countries and industries, diversity in the maturity of the technology transferred, variety in the competitive features of the related markets, etc.), we can consider that we benefit of stratified sample addressing the diversity of the contracting situations faced by traders of technologies. Moreover we are interested in the factors explaining the diversity of TLAs. We therefore need a sample characterized by its diversity, rather by the fact that its structure reflects the structure of the analyzed group.

${ }^{6}$ In Europe, due to the fragmentation of the political landscape, many TLAs are transnational while intraEuropean. In the same time the economy and the institutional framework is increasingly integrated at the regional level. We considered therefore licensing across European countries as domestic in the econometric.
} 


\section{2- The contractual governance design}

In the following section, we describe the three explained variables - supervision, renegotiation and dispute resolution provisions - which are our proxies for the design of the contractual governance mechanism. We also provide some descriptive statistics (table 3 ).

\section{1- Supervision}

In our sample, many agreements grant inspection rights aimed at controlling the licensee's usage of the licensed technology to the licensor or to a third party. The most common inspection right relates to the licensee's books ( $85 \%$ of the contracts). The contract grants inspection rights on the licensee's products and its industrial installations in $34 \%$ and $22 \%$ of the cases respectively. The licensee's R\&D projects are less frequently submitted to inspection rights $(10 \%)$.

Supervision of books is by itself a virtually cost-free activity. On the other hand, the inspection of products, facilities and R\&D programs is costly. This is why we differentiate between the contracts that do not implement a supervision mechanism or that implement the supervision of books alone, with those that implement supervision on other items. Moreover, the supervision of books is linked to the potential hazards on payments, rather than to contractual hazards related to the specifics of the knowledge (Brousseau and Coeurderoy, 2005).

We created a "supervision" variable, which takes a value of 0 when the contract either implements the supervision of books by itself, or, when the contract does not implement any inspection rights. A value of 1 is assigned if audit rights are granted on at least one of the following aspects of the licensee's concerns: its products, industrial installations or R\&D capacities.

\section{2- Renegotiation}

$40 \%$ of the contracts in our database involve a renegotiation provision. The royalty rate is subject to renegotiation in $18.3 \%$ of the cases, while the whole contract may be renegotiated in $15.5 \%$ of the cases. Renegotiation also concerns the geographical extension of the license in $13 \%$ of the cases, and the licensed technology itself in $12 \%$ of the agreements. In about one third of the contracts, a committee is created to manage the relationship between the parties. Such a formal renegotiation mechanism seems to be a more frequent in North America than in Japan or in Europe.

We therefore created the variable "Renegotiation", a dummy variable equal to 1 if the contract implements a renegotiation provision (which can range from the royalty rate or the geographical extension of the license to the whole contract) and equal to 0 otherwise.

\section{3- Dispute Resolution}

In order to ensure conflict resolution, agreements may implement various mechanisms. If nothing is specified in the contract, conflicts are implicitly brought to court, and conflict resolution costs are therefore partly externalized. This is the same if an internal committee is in charge of resolving contractual disputes. Indeed, if partners cannot reach an agreement, as a last resort courts are in charge of the settlements of conflicts. Alternatively, contractually specifying the recourse to an alternative dispute resolution mechanism — such as arbitrage - 
excludes a final appeal to courts. Conflict resolution costs are therefore totally borne by the partners.

Many contracts $(62 \%)$ in our sample implement a specific mechanism of dispute resolution. In most cases, either an independent arbitrator is contractually nominated (37\% of the cases) or the two parties agree to bring their conflict before a private instance such as a Chamber of Commerce or an industry union (27\%). Relying on a committee to solve disputes concerns only $10 \%$ of the agreements. The implementation of a specific dispute resolution mechanism is more common in North America (68\%) than in either Japan (52\%) or Europe (57\%).

We created the variable "conflict resolution device" that assumes a value of 0 if the contract does not implement a formal mechanism of dispute resolution, and a value of 1 if an ADR is settled.

$$
<\text { insert table } 3>
$$

\section{3- Explanatory variables}

As mentioned in section 1, the shape of contractual mechanisms is strongly influenced by the features of the transactions, the institutional framework and strategic considerations. Before detailing the proxies about each of these dimensions, it is necessary to clarify methodological issues in the econometrics of contracts.

\section{1- Methodological Choices}

We introduced in the set of explanatory variables contractual clauses that we consider to be good proxies for the characteristics of the relationship between the two parties. In our opinion, these contractual variables are related to the judgments made by contracting parties regarding the state of the technological and business features of their transaction. From that point of view, they are much better measures than generic data such as second hand industry indices of technology or competition.

We are aware however, that such a choice is potentially exposed to severe endogeneity biases in the right hand side variables (Masten and Saussier, 2000; Chiappori and Salanie, 2003). This is why we systematically checked that the estimations were not affected by such possible disturbances: estimations were made with only contractual variables and results were similar to those obtained with the complete model. We also tested a two-step procedure by running regressions of each contractual variable on other variables. This method helped check whether estimations would have been improved by the introduction of instrumental variables. Our results remained unchanged. We are therefore allowed to state that, in our sample, our right hand contractual variables are not seriously affected by endogeneity. Contracting parties seem to negotiate each strategic commitment rather autonomously from other commitments.

In addition we made sure that these contractual variables, which are, aimed at proxying some characteristics of the transaction and of the (competitive) relationship between the parties, are not linked by any logical causal relationship with the explained variables. 


\section{1- Transactional Characteristics of technology transfers}

Transaction cost economics focuses on three essential transactional attributes: asset specificity, uncertainty and frequency. The latter is meaningless in the case of technology and knowledge transfer given that most transactions are one shot. When it has been transmitted (and absorbed) by the recipient, it is pointless to transmit it again. As previously noted in the case of TLAs, the relational lock-in does not refer to investments in specific assets, but rather to the "investment" by the licensor in a costly and sunk transfer of its knowledge. Uncertainty refers mainly to technology.

\section{INTENSITY OF THE TRANSFER}

By means of factor analysis, we extracted one vector summarizing eleven dummies concerning the transfer of technology. The respondent explained whether the contract covers the transfer of one or more of the following: (i) the right to use other intellectual property rights (e.g. a trade secret) other than Trademark, (ii) the right to use Licensor's Trademark, (iii) plans, (iv) prototypes or material, (v) technical tests and development data, (vi) marketing tests and other commercial data, (vii) technical assistance and consultant services, (viii) accounting, marketing and management methods, (ix) training, (x) personnel delegation and (xi) other inputs such as products, equipment or services. We thereby established a continuum of contracts starting with those which do not organize any transfer of resources (but rather the right to use the patent) and ending in contracts characterized by multiple transfers. The construction is labeled by the variable "transfer intensity"

\section{TECHNOLOGICAL UNCERTAINTY}

In TLAs the main source of uncertainty that may affect governance mechanisms is related to technological developments. Indeed, they can make the principles and conditions of the exchange obsolete, thereby generating the need for ex post adaptation.

Uncertainty is a complex concept to operationalize in empirical analysis (Chiaporri and Salanie, 2003). In many studies, technological uncertainty is measured by a sectoral dummy (e.g., Anand and Khanna, 2000). This methodology is crude, however, since many different technologies matter in an industry. In addition, many technologies are used across industries while some are actually general-purpose technologies. It is therefore more relevant to measure the uncertainty at the transaction level. A wide empirical analysis in transaction cost economics has proposed proxies for technology uncertainty (Shelanski and Klein, 1996; Coeurderoy and Quélin, 1997). Questionnaires and measures by items of unobservable dimensions are the most common techniques given that they capture the perceptions by decision makers of the technological and business landscape.

In our research, we decided to rely on the assessment made by the contracting parties themselves. Two items in our questionnaire proxy the level of uncertainty: the implementation of grant-back provisions and the implementation of rights for the licensee to benefit from future improvements. A grant back provision enables the licensor to benefit from the right to appropriate the developments made by the licensee on the basis of its initial innovation (Caves et al., 1983, Bessy \& Brousseau, 1998). In a reversal of roles, it may be possible that the licensee can request to benefit from the future improvements made by the licensor. Contracting parties are likely to implement such provisions if they expect technological change throughout the life of the contract with potential consequences to the two parties contractual circumstances and to technological competition in general (Choi, 2002). We 
therefore created the variable "technological uncertainty" which takes a value of 0 if neither grant-back nor future improvement provisions are implemented, and a value of 1 if the contract specifies either one of the two, and a value of 2 if it includes both.

\section{2- The Influence of Institutional Environment}

\section{PUBLIC INSTITUTIONS}

To assess the impact of public institutional frameworks on contractual structures, we introduced a set of nine dummies describing the flow of technology transfer across geographical areas (e.g., us_us for a domestic licensing in the USA, or eur_jap for licensing from Europe to Japan). As the licensing contracts of the sample are designed within three large economic zones (North America, Europe and Japan), we assume that these zones reflect different levels of intellectual property rights protection and qualities of contractual law.

It is generally accepted that the strength of IPRs varies across countries, both because of the design of the law and of the organization of the institutions in charge of managing the IPRs system (Ostergard, 2000). However, these differences are difficult to measure because they depend upon many factors (including a lot of informal ones, such as the way courts document cases or make decisions). Most existing indicators are not satisfactory (e.g. La Porta et al., 1998). This is because they are highly biased by the goal of each of the particular studies (Sattin, 2002). In this paper we use the nationality of parties to qualify the IPRs regime. Even if there are still differences among European countries, the IPRs regime is increasingly standardized in Europe due to the existence of the European Patent Office and to the active policy of the European Union in this domain to achieve the realization of a single market. According to the literature, IPRs are stronger in the US than in Europe, and stronger in Europe than in Japan.

However, the structure of licensing agreements is not influenced by the IPRs regime only. Other dimensions of the legal framework, and in particular contract law, also play a role. It is therefore difficult to forecast precisely how the complex web of legal regulations impacts upon the design of contracts since various components of the law may have contrasting impacts. A more detailed analysis, based on a provision by provision basis, should therefore be carried out in the future. However, a larger sample would be needed to provide for the respective roles of the many (legal and non legal) explanatory factors of contractual structures.

\section{PRIVATE INSTITUTIONS}

The role of informal institutions was directly measured by asking if the agreements make any reference to information, regulation or service provided by private entities in an effort to simplify technology transfers. In our database, recourse to private institutions to the set-up of financial conditions is reported in $20 \%$ of the contracts (e.g. references to price index, tariffs or payment formulas). In $10 \%$ of the cases the settlement of technology transfer conditions refers to private institutions (e.g. "fair practice" guidelines). Private institutions also play a role in the supervision of parties' behavior in $12 \%$ of contracts (through for example the assessment of actual sales or production volume). This data is relatively homogeneous across countries and sectors.

In order to measure the influence of private institutions on the implementation of governance provisions, we then created the variable "private institutions", equal to 0 if the contract does 
not make reference to private institutions, and ranked from 1 to 4 according to the number of "services" provided by these entities: provision of "fair practice" or of financial guidelines, provision of information on parties' behavior (e.g. assessment of actual sales or produced volumes), dispute resolution procedures.

\section{3- Strategic Hazards Arising from Technological Competition}

We identified several proxies for the level of technological competition and potential conflict among contractors.

\section{LICENSOR's COMMITMENTS REGARDING PROPERTY RIGHTS}

The licensor can commit to the quality of the transferred intellectual property rights by granting the licensee three guarantees: (a) a warranty of ownership in which the licensor certifies that he is the actual and sole owner of the transferred knowledge, (b) a warranty of non infringement, which guarantees that title deeds are not subject to oppositions by other potential IPRs owners, and (c) an immunity from suit through which the licensor commits itself to defending the licensee against any suit related to the licensed technology . These guarantees are credible signals that firstly, the transferred IPRs are valuable in the sense that they are likely to generate income, and secondly, that the IPRs holder will invest in means to maintain its (and its licensees') exclusivity of access to the patented knowledge. By promising the licensee an actual exclusion of a source of rent in the case of contractual breach, these clauses implement a credible threat.

Such provisions are therefore proxies of both the value of the technology (the stakes of the transaction) and of the anticipation of possible conflicts about access to it. In order to take into account these commitments, we created the variable "IPRs commitment", which is a variable ranked from 0 to 2 according to the number of warranties the contract implements ${ }^{7}$.

\section{MINIMAL PERFORMANCES}

To prevent the licensee from inhibiting the use and diffusion of the technology (see section 21 ), the licensor can implement a provision for some minimum level of performance (assessed either by royalties, sales or production volumes). In our sample, $32 \%$ of the contracts implement such a minimal performance provision. In our opinion, this is a relevant proxy for potential technological competition between the parties given that only a competitor would have the incentive to become a licensee and hinder the use of a technology. We created the variable "minimal performance", a dichotomic variable equal to 1 if the contract implements minimal performances and otherwise to 0 .

\section{RENEWAL PROVISIONS}

Lastly, long-term involvement can also be expected to influence governance costs. Indeed, the licensee is more motivated to invest when the licensor commits itself in the long run. But in

\footnotetext{
${ }^{7}$ In our questionnaire for each of these three variables the respondent had a choice between three "levels" of commitment: no commitment by the licensor (0), partial commitment or limited warranty (1); full commitment (2). We checked, on the basis of Cronbach's alpha, — which measures how well a set of items (or variables) measures a single one-dimensional latent construction - that the assessment for the three items was correlated. We then calculated the mean value of the three items for this assessment of the licensor's commitment in guaranteeing the strength and the quality of intellectual title deeds.
} 
the long run uncertainty becomes greater. The longer the duration, the higher the risk of maladaptation. However, it is difficult to measure contract duration because many respondents did not provided us with the number of years for which the contract is implemented and often pointed out that the license was granted for the patent life. This would have been in any case very imprecise information since we neither know how old the patent is, nor whether technical change will allow patent exploitation until the end of its validity. We thus decided to proxy the horizon of the commitment between the parties through the presence of a renewal provision. Such a provision means that the parties anticipate that the patent will be maintained in the long run (or at least as long as the technology stay competitive) and that the licensee would like to maintain an option of access to the technology. This commitment by the licensor however will increase hazards given that the optimal licensing conditions may evolve. The licensor can therefore ask for a clause that will allow for the adaptation of contractual conditions given the changing business environment. We introduced the "renewal" variable, which is a dichotomic variable equal to the value of 1 in the event that the contract includes a provision of renewal ( $52 \%$ of cases), and equal to the value of 0 otherwise.

\section{4- Other Control Variables}

Finally, other factors should also affect the governance structure of contracts. We took into account industry features, equity relationships, and licensor size.

\section{SECTORAL DUMMIES}

As previously mentioned, we divided our sample into five industries (chemical related activities being used as the industry of reference). The industry in which the technology transfer occurs has been used in many studies as a proxy of both the presence of informal institutions and technological uncertainty (e.g. Anand and Khanna, 2000, Bessy, Brousseau and Saussier, 2002). Since we have the opportunity to use more precise proxies for these two elements, we use a sectoral dummy in order to control for any other sectoral effects, such as the industry structure or the level of technological interdependence.

\section{EQUITY LINKS}

Among subsidiaries of a same firm or between a subsidiary and its parent company, there exist additional governance mechanisms that will decrease enforcement costs. Consequently, we created the variable "equity links" which will take into account the existence of an equity relationship between the licensor and the licensee. We expect equity links to decrease the probability of contractual governance clauses.

\section{THE FIRM'S SIZE}

A larger firm is more likely to possess the adequate resources and also be able to dedicate the adequate level of effort and expertise needed for the management of its licensing activities. Moreover, it has a higher probability of benefiting from learning effects. Size can therefore affect the management of licensing contracts. We discriminate our sample according to the licensor's size, distinguishing between firms employing less than 500 employees and those employing more than 500 ("licensor's size" variable).

\section{4-Analysis of Results}


In this specific piece of research, we study the design of contractual governance resulting from the three simultaneous decisions made by the licensor:

- the decision to closely supervise how the licensee use the licensed technology;

- the decision to explicitly anticipate the need for ex post adaptation and to therefore implement a renegotiation mechanism;

- the decision to implement an alternative dispute resolution mechanism.

However, like Anand and Khana (2000), we consider that the choices of contractual clauses are likely to be made simultaneously given that they inter-related in the contractual governance decision. It is therefore necessary to assess the potential joint incidence of the three contractual clauses.

Moreover, we use one dummy variable for each contractual clause. Consequently, we use a multivariate probit model estimated by simulated maximum likelihood, available within STATA software (Cappelari and Jenkins, 2003). The multivariate probit model uses the Geweke-Hajivassiliou-Keane (GHK) simulator to evaluate the M-dimensional Normal integrals in the likelihood function. For each observation, a likelihood contribution is calculated for each replication, and the simulated likelihood contribution is the average of the values derived from all the replications. The simulated likelihood function for the sample as a whole is then maximized using standard methods. Furthermore we use the Huber/White/Sandwich estimator of variance in place of the traditional calculation. This alternative variance estimator produces consistent standard errors when observations are not fully independent ${ }^{8}$.

Our regression model of contractual governance is thus an $\mathrm{M}$ equation multivariate probit model as follows:

$\mathrm{Y}_{\mathrm{im}}{ }^{*}=\beta_{\mathrm{m}}{ }^{\prime} \mathrm{X}_{\mathrm{im}}+\varepsilon_{\mathrm{im}}, \mathrm{m}=1, \ldots, \mathrm{M}$

$\mathrm{y}_{\mathrm{im}}=1$ if $\mathrm{y}_{\mathrm{im}} *>0$ and 0 otherwise

$\varepsilon_{\mathrm{im}}, \mathrm{m}=1, \ldots, \mathrm{M}$, are error terms distributed as multivariate normal, each with a mean of zero, and variance-covariance matrix $\mathrm{V}$, where $\mathrm{V}$ has values of 1 on the leading diagonal and correlations $\rho j \mathrm{k}=\rho \mathrm{kj}$ as off-diagonal elements (Cappelari and Jenkins, 2003).

Results are provided in table 4 and discussed below.

$$
<\text { insert table } 4>
$$

\section{1-Supervision}

Our results confirm the close link between the intensity of the transfer - and therefore the lock-in between the parties due to switching costs — and the preference for supervision. We

\footnotetext{
${ }^{8}$ In our sample respondents provide answers for several contracts.
} 
provide one more piece of evidence supporting the TCE conjecture that a transaction exposed to appropriability hazards requires a more protective mode of governance (Williamson, 1985; Oxley, 1999). In general such an argument is tested through the trade-off of "licensing versus direct investment". Here we provide evidence of the impact of ex post issues on the design of the contract.

The second salient feature is the licensor's commitment in guaranteeing the quality and the strength of its intellectual title deeds. Protected technologies are more likely to be valuable and are therefore more exposed to risks of opportunistic appropriation. The licensor implements a supervision provision to provide for this risk. This confirms the limits of ex ante safeguards and the need to monitor opportunism ex post. Since we consider a provision for minimal performance as a proxy for the intensity of the technological competition among the parties, it is as expected positively correlated to supervision. Other transaction features and strategic variables do not significantly impact on supervision

Our results also show the influence of the institutional framework. Firstly, private institutions clearly matter. They positively influence the recourse to supervision. The implementation of bilateral supervision is therefore complementary to the provision of other coordination services provided by private institutions, which in line with MacNeil (1974), contribute to secure bilateral relationships.

Secondly, our results also show the importance of the public institutional framework. The most stringent result is that the presence of a US partner significantly increases the probability of implementing a supervision mechanism. It confirms the idea raised by the contributions of scholars such as La Porta, Lopez-de-Silanes and Visnhy (1999) that the US legal system has more internal conflict than the European institutional system due to the influence of Common Law in the US (whereas the latter is more based on Roman law or Civil Code). Our results also confirm that inter-zone agreements are influenced by the institutional complexity and uncertainty that face agents when they trade IPRs across national boundaries. Except for licensing from the USA to Japan, in which the coefficient is lower than for domestic licensing, cross-borders licensing contracts exhibit systematically higher coefficients than the domestic benchmark. International transfers of technologies induce a more intensive use of supervision. However, this positive relationship is not systematic and bilateral. For example, European firms are more likely to implement a supervision mechanism when they export technology to Japan, than is the case of the reverse. Such results however are difficult to interpret since our sample is too small to for any generalization.

Furthermore, there is noticeable diversity in supervision across industries (the reference being the chemical industry). In particular, attention should be drawn to a more intense supervision in the raw materials and in the service industries. This is probably linked to the fact that most patented technologies in these industries are process technologies. IPRs infringement on technologies implemented in processes is more difficult to detect than infringement of a product technology.

Firm-specific variables (size and equity partnership) are not influential in the supervision decision. Since the recourse to supervision is linked to judicial enforcement in the last resort, this suggests that access to such public enforcement resources is not discriminatory among firms. 


\section{2- Renegotiation Provision}

By granting a renewal provision, the licensor explicitly provides ex ante a long-term commitment. As expected, a renegotiation clause is included as a safety net. On one hand, the licensee will improve his prospects of expected profits; while on the other hand, the licensor keeps the opportunity to adjust the contractual terms in the case of misalignment. Renegotiation as a means to readjusting transactions is also visible in the impact of technological uncertainty (albeit only significant at a 10\% threshold). Since most industry dummies are not significant, despite great variations in technological settings, it confirms the idea that technological uncertainty is a significant variable at the micro-level of transactions and technological domain only.

We also note that the renegotiation clause is more likely to be implemented when private institutions support licensing activities. It is therefore confirmed that when such private bodies provide a framework underlying party behavior, renegotiations are more easily considered as a way of realigning mutual behavior. Again McNeil's analysis (1974) analysis of relational contracting seems to be validated.

It may be surprising to discover that there is no significant relationship between supervision provisions and the level of specific "investment" in the transaction. But, as explained previously, transferred knowledge is a sunk cost and so negotiation would be pointless.

\section{3-Dispute Resolution Mechanisms in Licensing Contracts}

The confirmed strong correlation between ADR provision and the existence of private institutions is consistent with the idea that an ADR is required when the governed transactions are so specific that conflicts cannot be easily settled by the courts. Again, MacNeil's vision prevails. Despite great variation in the organization of industry settings, because industry dummies are not significant, it confirms that relevant private institutional frameworks, are, as pointed out by Bessy and Brousseau (1998), organized at the "technological domain" level and not at the industry level.

High levels of contractual hazards reduce the likelihood to implement an ADR as shown by the negative influence of technological uncertainty. Technological uncertainty raises the level of potential contractual hazards because it hampers the protection provided by IPRs. This is due to the fact that experts do not share a common vision of the technology.

Furthermore, equity links are influential on the choice of an ADR. They decrease the need to formally recourse to an ADR since parties can rely on "hierarchical" means to solve conflicts.

We can also note that neither the geographical origins of the licensor nor the international character of the transfer, impact on the design of dispute resolution mechanisms. There is no impact of formal institutions. In fact, only the transfers from Europe to Japan lead to the implementation of an ADR mechanism, which seems hard to interpret from ten cases. This therefore confirm that the implementation of an ADR is strongly linked to final enforcement by private and informal institutions 


\section{4-The Dependence among Contractual Provisions}

We checked whether the choices of the three governance provisions are independent or not. As table 4 shows, the overall hypothesis of independence for the three regression models is not rejected. We therefore confirm that supervision, renegotiation and dispute resolution provisions follow distinct purposes on a whole.

Note however, the significant and negative relationship concerning the bilateral test of supervision and alternative dispute resolution (rho31). This result indicates "interdependence" between the two decisions. When a licensor prefers to assume supervision effort, he will be more reluctant to rely on an ADR (and vice versa). This interdependence can be explained by the degree of conflict within the relationships and by the relevant institutional framework to deal with it. In case of a low degree of conflict, supervision is less likely to be implemented, while an ADR is easier to implement. More cooperative solutions framed by informal and private institutions take place. A high degree of conflict leads to the implementation of contractual provisions which will, in the last resort, be guaranteed by courts.

These results call for more detailed analyses in the design of contractual mechanisms. Indeed, contracts are made of set of provisions addressing different issues (e.g. supervision, renegotiation, dispute resolution). It is of importance for the theory of contracts to state whether these different provisions are designed independently of one another. Two visions can be developed:

i. The first vision is linked to the idea that the performances of contractual components are intertwined, an idea which corresponds to the mathematical property of supermodularity (Holmström and Milgrom, 1994; Athey and Stern, 1998 ; Brickley, 1999). This leads to the idea that polar forms of governance and therefore of contract, exist. This fits with the idea proposed by Williamson (1991) that economic agents choose among a reduced set of possible governance/contractual modes, which may for example correspond to "markets", "hybrids" or "hierarchies".

ii. The second vision is linked to the idea that contractual components address independent coordination problems. This leads to a modular conception of contracts in which provisions are chosen independently of each other. The large number of possible combinations of contractual clauses result in a vision of a continuum of contracts from the market to the hierarchy.

Of course, the two visions might be combined by pointing out that there are strong complementarities among some types of contractual mechanisms, and independence among others that might explain variations around polar forms (Brousseau, 1995).

Better understanding of the complementarities among contractual mechanisms is a complex challenge, in particular for applied analysis due to the fact that it is highly data demanding (see Arora, 1996). Our results however, seem to support the idea that the design of certain components of contractual governance is partly independent. Nevertheless, we do not provide any test rejecting the idea that complementarities do not exist. Several elements suggest that complementarities also exist. For instance, we pointed out several times that there are obvious links between some decision made about the design of the ex ante mechanisms - e.g. the payment formulae - and the ex post governance mechanisms - e.g. supervision on books when royalties are implemented. Contracts therefore seem marked by the co-existence of independence and complementarities among their mechanisms. 


\section{5- Concluding Remarks}

Table 5 sums up the most important econometric outcomes.

$<$ insert table $5>$

Generally speaking most of our hypotheses are confirmed. Table 5 confirms that the analyzed contractual provisions are not explained by the same variables, leading to the idea that they address different contractual hazards. Moreover many contractual solutions appear to be associated with different necessary conditions. This justifies our approach that deals simultaneously with transactional, institutional and strategic determinants of contractual features (and therefore of transaction costs). In addition, the identified complementarities correspond to the idea that contracts are made up partly from independent mechanisms.

In a nutshell, a formal supervision mechanism aimed at controlling potential contractual hazards, is likely to be implemented only when it is possible - because the formal institutional environment implements well-defined IPRs that are efficiently enforced by the judicial system - and necessary - when the licensor is subject to contractual hazards both because he has to invest significantly to transmit knowledge (resulting in lock-in), and because he can contract with partners that could become competitors.

A renegotiation mechanism aimed at enabling mutual adjustment ex post, is likely to be implemented when uncertainty and a long-term horizon prevent the party from writing a complete contract ex ante. Private institutions appear particularly useful in creating a framework for the renegotiation process.

Implementing an ADR mechanism is submitted to strong conditions because of the irreversible and huge consequences of behavioral hazards in the case of the transfer of knowledge. Private institutions in particular, seem to favor the implementation of an ADR since they frame the behavior of agents.

More generally, our results provide evidence on the influence of private institutions on technology markets. By facilitating the exchange of information among firms and agreement regarding the norms of behavior, these entities simplify technology transfers and clarify the rules of the game in the business. Public authorities should favor their development instead of considering them as organizations aimed at favoring collusion and anti-competitive practices.

Despite a number of verifications and controls, we know that our estimations can still be partially impacted by biases and misspecifications. At the same time, we can confidently assert that our key findings are sound enough to provide new evidence on the main transactional, institutional and strategic determinants of the shape of technology licensing agreements. We hope that these results will encourage economists to further empirically research the design of contractual governance mechanisms. In particular, accurate proxies for the quality of the legal and institutional environment for the case of IPRs, should allow for better understanding as to how public institutions shape the environment of knowledge-based transactions. It would be a key contribution to the design of institutional frameworks favoring the development of a market for technologies. 


\section{References}

Anand, B.N., Khanna, T. [2000], "Intellectual Property Rights and Contract Structure”, Journal of Industrial Economics, XLVIII, 103-135.

ArorA A. [1995], Licensing Tacit Knowledge : Intellectual Property Rights and the Market of Know-How, Economics of Innovation and New Technology, Vol.4, pp. 41-59.

ARORA A. [1996], "Testing for complementarities in reduced-form regressions: A note," Economics Letters, vol. 50(1), pages 51-55.

Arora, A. , Fosfuri, A. [2002] "Licensing in the Chemical Industry", in: E. Brousseau and J-M. Glachant (eds.), The Economics of Contracts: Theories and Applications, Cambridge University Press.

Arora, A., Fosfuri, A. and Gambardella, A. [2001], Markets for Technology: The Economics of Innovation and Corporate Strategy, MIT Press.

Athey, S. , Stern, S. [1998], “An Empirical Framework for Testing Theories about Complementarities in Organizational Design”, NBER working paper 6600.

Aulakh, P.S., CAVusgil, S.T. and SARKAR, M.B. [1998], "Compensation in International Licensing Agreements”, Journal of International Business Studies, 29(2), 409-419.

BARZEL, Y. [1989], The Economics of Property Rights, Cambridge University Press.

BernsteIn, L. [2001], "Private Commercial Law in the Cotton Industry: Creating Cooperation through Norms, Rules, and Institutions”, Michigan Law Review, 99, 1724-1788.

Bessy, C. , Brousseau, E. [1998], “Technology Licensing Contract: Features and Diversity”, International Review of Law and Economics, 18, 451-489.

Bessy C., Brousseau E. SAussier, S. [2002], "Payment Schemes in Technology Licensing Agreements: a Transaction Cost Approach", Working Paper, FORUM, University of Paris X, ATOM, University of Paris I.

Bessy, C., Brousseau, E. , Saussier, S. [2003], "Safeguards and Governance Mechanisms in Contractual Relationships: The Case of Technology Licensing Agreements", Working paper ATOM, University Paris Sorbonne.

BRICKLEY, J. [1999], "Incentive Conflicts and Contractual Restraints: Evidence from Franchising”, Journal of Law, Economics, 42(2), 745-774

Brousseau E. , Bessy, C. [2005], "Public and Private Institutions in The Governance of Intellectual Property Rights” in: B. Andersen (ed.), Intellectual Property Rights: Innovation, Governance and the Institutional Environment, Edward Elgar Publishers, Forthcoming

Brousseau E., Chaserant C and Bessy C. [2005], The Diversity of Technology Licensing Agreements and their Causes : An International Survey on Technology Licensing Practices, Report for the LES International, Miméo, University of Paris X, Paris, October.

Brousseau E., C Chasserant, C. Bessy, \& R. Coeurderoy, 2005, “The Diversity Of Technology Licensing Agreements And Their Causes", December, XL : 4, p. 179-200

Brousseau, E. [1995], "Contracts as Modular Mechanisms: Some Propositions for the Study of 'Hybrid Forms"”, International Journal of the Economics of Business, 2(3), 409-439.

Brousseau, E. and Coeurderoy, R. [2005], "The Governance of Intellectual Property Rights in Knowledge Transfers: An Empirical Analysis of Supervision Provisions in Technology Licensing Agreeme," International Journal of the Economics of Business, Taylor and Francis Journals, vol. 12(3), pages 403-424.

Brousseau E. and Fares, M. [2000], “The Incomplete Contract Theory and the New-Institutional Economics Approaches to Contracts: Substitutes or Complements?", in: C. Ménard (ed.), Institutions, Contracts, Organizations, Perspectives from New-Institutional Economics, Edward Elgar Pub. 
Brousseau, E. [2004], "Property Rights in the Digital Space", in E. Colombatto (ed), Companion to Economics of Property Rights, Edward Elgar Pub.

Brousseau, E., Fares M. and Raynaud E. [2004], “The Economics of Private Institutions", 8th ISNIE Conference - Tucson, USA, September.

CAPPelari, L. and Jenkins, S. [2003], "Multivariate Probit Regression Using Simulated Maximum Likelihood", The Stata Journal, 3(3), 221-222.

Caves, E., Crookel, H. and Killing, P.J. [1983], “The Imperfect Market for Technology Licenses”, Oxford Bulletin of Economics and Statistics, 45, 249-267.

CHI, and RoEHL, [1997], "The Structuring of Interfirm Exchanges in Business Know-how: Evidence from International Collaborative Ventures.", Managerial and Decision Economics, (18) 279-294.

ChIAPPORI, PA. SALANIE, B. [2003], "Testing Contract Theory: a Survey of Some Recent Work', in Advances in Economics and Econometrics - Theory and Applications, Eighth World Congress, M. Dewatripont, L. Hansen and P. Turnovsky, ed., Econometric Society Monographs, Cambridge University Press, Cambridge, 115-149.

CHOI, J. [2002]."A Dynamic Analysis of Licensing: the "Boomerang" Effect and Grant-Back Clauses", International Economic Review, 43, 803-829.

Cockburn, I., Henderson, R. and Stern, S. [2000], "Balancing Incentives: The Tension between Basic and Applied Research", Working Paper, MIT, Sloan School of Business.

Coeurderoy, R. B. Quelin [1997], "L'économie des coûts de transaction: Un bilan des études empiriques sur l'intégration verticale," Revue d'Economie Politique, 107, 145-181.

Crocker, K.J. and MASTEN, S. [1991], "Pretia ex machina? Prices and process in long-term contracts", Journal of Law and Economics, 34, 69- 99.

DAVIES, H. [1977].’Technology Transfers through Commercial Transactions", Journal of Industrial Economics, $26,161-175$.

DAVIES, H. [1992]."Some Differences between Licensed and Internalized Transfers of Machine Tool Technology: an empirical Note", Journal of Industrial Economics, 13, 539-541.

GAllini, N. and WinTER, R. [1985], "Licensing in the theory of innovation", Rand Journal of Economics, 16, 237-252.

Ginarte, J. C. and PARK, W. G. [1997], "Determinants of Patent Rights: A Cross-National Study", Research Policy, 26, 283-301.

HAdFIELD, G. [2005], "The Many Legal Institutions that Support Contractual Commitments”, in C. Ménard, M. Shirley (eds.), Handbook of New Institutional Economics, Kluwer Academic Publishers, 175-204.

Hart, O., and Holmström, B [1987], "The Theory of Contracts", in: T. Bewley (ed), Advances in Economic Theory, Cambridge University Press.

Holmström, B. and Milgrom, P. [1994], “The Firm as an Incentive System”, American Economic Review, 84, 972-991.

ICHNiOWski, C.K., Shaw, K. and Prennushi, G. [1997], "The Effects of Human Resource Management Practices on Productivity", American Economic Review, 87(3), 291-313.

JAFFE A. B., LERNER J, [2004], Innovation and Its Discontents: How Our Broken Patent System is Endangering Innovation and Progress, and What to Do About It, Princeton University Press

JORDE, T.M. and TEECE, D.J. [1990], "Innovation and Cooperation: Implications for Competition and Antitrust", Journal of Economic Perspectives, 4(3), 75-96.

KAMIEN, [1992], "Patent licensing”, Chapter 11 in Handbook of Game Theory, Eds. R. J. Aumann and S. Hart.

Klein, P. and Shelanski, H. [1995], "Empirical Research in Transaction Cost Economics: A Survey and Assessment", Journal of Law, Economics and Organisation 11, 335-362.

KnACK S. and KeEFer, P. [1995], "Institutions and Economic Performance: Cross-Country Test Using Alternative Institutional Measure", Economic and Politics, 7, 207-227. 
La Porta, R., Lopez-De-Silanes, F., Schleifer, A. and Vishny, R. [1998], "Law and Finance”, Journal of Political Economy, 106, 1113-1155.

La Porta, R., Lopez-De-Silanes, F., Schleifer, A. and Vishny, R. [1999], "The Quality of Government", Journal of Law, Economics, and Organization, 15(1), 222-282.

Macho-Stadler I, Martinez-Giralt X, Perez-Castrillo D. J. [1996], "The Role of Information in Licensing Contract Design”, Research Policy, 25, 43-57.

MACNEIL, I.R. [1974], “The many futures of contracts”, Southern California Law Review, 47, 691-816.

MASTEn S. , SAUSSIER S. [2001], "Econometrics of Contracts: An Assessment of Developments in the Empirical Litterature of Contracting" in Economics of Contracts: Theories and Applications, Brousseau E. \& Glachant J-M Eds, Cambridge University Press.

NORTH, D. [1990], Institutions, Institutional Change and Economic Performance, Cambridge University Press.

NoRTH, D. [2005], Understanding the Process of Economic Change, Princeton University Press, forthcoming.

OSTERGARD, R.L. [2000], “The Measurement of Intellectual Property Rights Protection”, Journal of International Business Studies, 31, 349-361.

OXLEY, J.E. [1999], "Institutional Environment and the Mechanisms of Governance: the Impact of Intellectual Property Protection on the Structure of Inter-Firm Alliances", Journal of Economic Behavior and Organization, 38, 283-309.

PREndergast, C. [1999], “The Provision of Incentives in Firms”, Journal of Economic Literature, 37, 7-63.

SATTIN, J.-F. [2002], "Institutional Environment and Transfer of Intellectual Property Rights: An Econometric Study on French Foreign Licensing", Proceedings from the Sixth Annual Conference of the International Society for New Institutional Economics, MIT, Cambridge.

Shelanski, H. Klein, P. [1995], "Empirical Research in Transaction Cost Economics: A Review and Assessment”, 11, Journal of Law, Economics, and Organization, 335-361.

SHEPARD, A. [1987], "Licensing to Enhance Demand for New Technologies", Rand Journal of Economics, 18, 630-638.

TEECE, D. [1977], “Technology Transfer by Multinational Firms: The Resource Cost of Transferring Technological Know-How", Economic Journal, 87, 242-261.

TEECE, D. [1986], "Profiting from technological innovation: Implications for integration, collaboration, licensing and public policy", Research Policy, 15, 285-305.

TIROLE, J. [1988], The Theory of Industrial Organization, MIT Press.

Williamson, O.E. [1975], Markets and Hierarchies. Analysis and Antitrust Implications, The Free Press.

Williamson, O.E. [1985], The Economic Institutions of Capitalism, The Free Press.

Williamson, O.E. [1991], "Comparative Economic Organization: the Analysis of Discrete Structural Alternatives", Administrative Science Quarterly, 36(2), 269-296.

Williamson, O.E. [1996], The Mechanisms of Governance, Oxford University Press. 
Table 1: Characteristics of the Respondents to the Questionnaire (in \%)

\begin{tabular}{|r|c|c|c|c|}
\hline \multicolumn{1}{|r|}{ Country } & $\begin{array}{c}\text { North } \\
\text { America }\end{array}$ & Europe & Japan & Total \\
\hline $\begin{array}{r}\text { Industries } \\
\text { (1)Transformation of raw materials }\end{array}$ & 10.48 & 11.67 & 17.24 & 11.74 \\
(2) Chemicals & 50.00 & 23.33 & 41.38 & 41.31 \\
(3) Equipment manufacturing & 20.16 & 21.67 & 37.93 & 23.00 \\
(4) Services & 12.10 & 38.33 & 0.00 & 17.84 \\
(5) Other & 7.26 & 5.00 & 3.45 & 6.10 \\
\hline Total & & & & \\
& & & & \\
\hline
\end{tabular}

Table 2a The Geographic Distribution of our Contracts (in \%)

\begin{tabular}{|c|r|r|r|r|}
\hline & \multicolumn{4}{|c|}{ Licensor's region } \\
\hline Licensee's region & \multicolumn{1}{|c|}{ USA } & \multicolumn{1}{|c|}{ Japan } & Europe & Total \\
\hline \multirow{2}{*}{ usa } & 79 & 9 & 18 & 106 \\
& 63.71 & 31.03 & 30.00 & 49.77 \\
\hline \multirow{2}{*}{ Japan } & 28 & 13 & 10 & 51 \\
& 22.58 & 44.83 & 16.67 & 23.94 \\
\hline \multirow{2}{*}{ Europe } & 17 & 7 & 32 & 56 \\
& 13.71 & 24.14 & 53.33 & 26.29 \\
\hline Total & 124 & 29 & 60 & 213 \\
\hline
\end{tabular}

Table 2b: Characteristics of the Contracts of the Sample (in \%)

\begin{tabular}{|c|c|c|c|c|}
\hline $\begin{array}{ll}\text { Partner's description } & \text { Country }\end{array}$ & $\begin{array}{l}\text { North } \\
\text { America }\end{array}$ & Europe & Japan & Total \\
\hline Same country & 63.71 & 53.33 & 44.83 & 58.22 \\
\hline Same industry & 55.65 & 60.00 & 82.76 & 60.56 \\
\hline Same size & 41.94 & 53.33 & 79.31 & 50.70 \\
\hline Prior licensing agreement & 20.16 & 27.12 & 48.28 & 25.94 \\
\hline Equity relationship & 20.97 & 18.33 & 20.69 & 20.19 \\
\hline $\begin{array}{cl}\text { Nature of the agreement } \\
\text { - } & \text { Sole license } \\
\text { - } & \text { R\&D project } \\
\text { - } & \text { Partnership } \\
\text { - } & \text { Alliance } \\
\text { - } & \text { Other }\end{array}$ & $\begin{array}{c}57.50 \\
20.00 \\
9.17 \\
12.50 \\
0.83\end{array}$ & $\begin{array}{c}63.79 \\
10.34 \\
8.62 \\
15.52 \\
1.72\end{array}$ & $\begin{array}{c}62.07 \\
24.14 \\
10.34 \\
3.45 \\
0.00\end{array}$ & $\begin{array}{c}59.90 \\
17.87 \\
9.18 \\
12.08 \\
0.97\end{array}$ \\
\hline Total number of responses & 124 & 60 & 29 & 213 \\
\hline
\end{tabular}

Table 3: Characteristics of the governance clauses (in \%)

\begin{tabular}{|l|c|c|c|c|}
\hline Frequency of clauses implementation & America & Europe & Japan & Total \\
\hline Supervision & 45.16 & 35.00 & 44.83 & 42,25 \\
Renegotiation & 36.29 & 40.00 & 51.72 & 39.44 \\
Alternative Dispute Resolution & 67.74 & 56.67 & 51.72 & 62.44 \\
\hline Total number of responses & 124 & 60 & 29 & 213 \\
\hline
\end{tabular}


Table 4 Joint Analysis of Contractual Clauses Mechanism (Multivariate probit model)

\begin{tabular}{|c|c|c|c|}
\hline & supervision & Renegotiation & conflict resolution \\
\hline \multirow[t]{2}{*}{ transfer intensity } & $0.621 * *$ & -0.025 & -0.027 \\
\hline & $(0.229)$ & $(0.206)$ & $(0.210)$ \\
\hline \multirow[t]{2}{*}{ renewal } & -0.124 & $0.689 * * *$ & -0.305 \\
\hline & $(0.216)$ & $(0.202)$ & $(0.227)$ \\
\hline \multirow[t]{2}{*}{ Techno. uncertainty } & -0.118 & $0.195^{\circ}$ & $-0.215^{*}$ \\
\hline & $(0.124)$ & $(0.124)$ & $(0.135)$ \\
\hline \multirow[t]{2}{*}{ IPRs commitment } & $0.117 *$ & 0.053 & 0.077 \\
\hline & $(0.060)$ & $(0.058)$ & $(0.069)$ \\
\hline \multirow[t]{2}{*}{ minimal performance } & $0.437 *$ & 0.300 & 0.240 \\
\hline & $(0.230)$ & $(0.228)$ & $(0.250)$ \\
\hline \multirow[t]{2}{*}{ private institutions } & $0.244 *$ & $0.236 *$ & $0.486 * * *$ \\
\hline & $(0.107)$ & $(0.104)$ & (0.109) \\
\hline \multirow[t]{2}{*}{ raw material } & $1.429 * * *$ & 0.213 & -0.435 \\
\hline & (0.396) & $(0.343)$ & $(0.361)$ \\
\hline \multirow[t]{2}{*}{ equipment } & $0.705 * *$ & $0.514^{\circ}$ & -0.190 \\
\hline & $(0.278)$ & $(0.291)$ & $(0.306)$ \\
\hline \multirow[t]{2}{*}{ other } & $1.341 * *$ & 0.084 & -0.916 \\
\hline & $(0.492)$ & $(0.427)$ & $(0.642)$ \\
\hline \multirow[t]{2}{*}{ services } & $0.873 * *$ & 0.089 & -0.428 \\
\hline & $(0.326)$ & $(0.313)$ & $(0.342)$ \\
\hline \multirow[t]{2}{*}{ equity links } & 0.388 & 0.202 & $-0.942 * * *$ \\
\hline & $(0.250)$ & $(0.253)$ & $(0.284)$ \\
\hline \multirow[t]{2}{*}{ large enterprise } & -0.196 & 0.322 & 0.413 \\
\hline & $(0.272)$ & $(0.258)$ & $(0.294)$ \\
\hline \multirow[t]{2}{*}{ us_us } & $1.188 * * *$ & -0.080 & 0.10 \\
\hline & $(0.356)$ & $(0.300)$ & $(0.331)$ \\
\hline \multirow[t]{2}{*}{ us_jap } & $1.027 * *$ & 0.033 & 0.330 \\
\hline & $(0.414)$ & $(0.386)$ & $(0.385)$ \\
\hline \multirow[t]{2}{*}{ us_eur } & $1.900 * * *$ & -0.087 & -0.638 \\
\hline & $(0.463)$ & $(0.376)$ & $(0.508)$ \\
\hline \multirow[t]{2}{*}{ jp_us } & $2.474 * * *$ & 0.507 & -0.239 \\
\hline & $(0.650)$ & $(0.565)$ & $(0.711)$ \\
\hline \multirow[t]{2}{*}{ jp_jap } & 0.900 & 0.007 & 0.535 \\
\hline & $(0.595)$ & $(0.504)$ & $(0.480)$ \\
\hline \multirow[t]{2}{*}{ jp_eur } & $1.047^{\circ}$ & -0.290 & $1.151 *$ \\
\hline & $(0.598)$ & $(0.568)$ & $(0.578)$ \\
\hline \multirow[t]{2}{*}{ eur_us } & $1.324 * *$ & -0.234 & -0.121 \\
\hline & $(0.450)$ & $(0.390)$ & $(0.433)$ \\
\hline \multirow[t]{2}{*}{ eur_jap } & $1.331 * *$ & 0.212 & $1.450 * *$ \\
\hline & $(0.494)$ & $(0.526)$ & $(0.504)$ \\
\hline \multirow[t]{2}{*}{ _intercept } & $-2.264 * * *$ & $-1.643 * * *$ & -0.489 \\
\hline & $(0.498)$ & $(0.419)$ & $(0.454)$ \\
\hline Rho 21 & & -0.003 & \\
\hline & & $(0.127)$ & \\
\hline Rho 31 & & $-0.277 *$ & \\
\hline & & $(0.136)$ & \\
\hline Rho 32 & & 0.038 & \\
\hline & & $(0.137)$ & \\
\hline $\mathrm{N}$ & & 213 & \\
\hline Log pseudo likelihood & & -322.81 & \\
\hline Wald chi square & & $166.37 * * *$ & \\
\hline
\end{tabular}

Likelihood ratio test of rho21 $=$ rho31 $=$ rho32 $=0 ; \operatorname{chi} 2(3)=3.9166 \quad$ Prob $>$ chi2 $=0.2706$. Coefficients significant at 1\%o (***); $1 \%(* *) ; 5 \%(*) ; 10 \%\left({ }^{\circ}\right)$. 
Table 5. Synthesis of the Results

\begin{tabular}{|c|c|c|c|}
\hline & $\begin{array}{l}\text { Supervision } \\
\text { Mechanism } \\
\end{array}$ & Renegotiation & $\begin{array}{l}\text { Alternative Dispute } \\
\text { Resolution (Ext) }\end{array}$ \\
\hline \multicolumn{4}{|l|}{ Transaction's Features } \\
\hline Transfer Intensity & + & & \\
\hline Technological Uncertainty & & + & -- \\
\hline \multicolumn{4}{|l|}{ Strategic Bias } \\
\hline Commitment to Maintain Strong IPRs & + & & \\
\hline Minimal Performance & + & & \\
\hline Contract Renewal & & + & \\
\hline \multicolumn{4}{|l|}{ Institutional Environment } \\
\hline $\begin{array}{ll}\text { Regional Origin of the } & \begin{array}{l}\text { North America } \\
\text { Japan } \\
\text { Contractors }\end{array} \\
& \text { Europe } \\
\end{array}$ & + & & \\
\hline Internationalization of the exchange & + & & \\
\hline Recourse to Private Institutions & + & + & + \\
\hline \multicolumn{4}{|l|}{ Control Variables } \\
\hline $\begin{array}{l}\text { Equipment } \\
\text { Service } \\
\text { Raw Material } \\
\text { Other }\end{array}$ & $\begin{array}{l}+ \\
+ \\
+ \\
+\end{array}$ & + & - \\
\hline Equity Links & & & - \\
\hline Licensor's size & & & \\
\hline
\end{tabular}

